EUROPE AND THE THIRD WORLD 


\section{Themes in Comparative History}

General Editor: Clive Emsley

\section{Published Titles}

Clive Emsley Policing and its Context, 1750-1870

R. F. Holland European Decolonization, 1918-1980

Ian Inkster Science and Technology in History

Dominic Lieven The Aristocracy in Europe, 1815-1914

Rosemary O'Day The Family and Family Relationships, 1500-1900:

England, France and the United States of America

Pamela Pilbeam The Middle Classes in Europe, 1789-1914

Jane Rendall The Origins of Modern Feminism:

Women in Britain, France and the United States, 1780-1860

Bernard Waites Europe and the Third World:

From Colonisation to Decolonisation, c. 1500-1998

Ken Ward Mass Communications and the Modern World

\section{Forthcoming}

David Englander and Tony Mason War and Politics:

The Experience of the Serviceman in Two World Wars

Joe Lee Peasant Europe in the Eighteenth and Nineteenth Centuries

Peter Rycraft Peasant Rebellions, 1400-1600 


\title{
EUROPE AND THE THIRD WORLD
}

From Colonisation to Decolonisation c.1500-1998

\author{
Bernard Waites \\ Lecturer in European Humanities \\ The Open University
}


All rights reserved. No reproduction, copy or transmission of this publication may be made without written permission.

No paragraph of this publication may be reproduced, copied or transmitted save with written permission or in accordance with the provisions of the Copyright, Designs and Patents Act 1988, or under the terms of any licence permitting limited copying issued by the Copyright Licensing Agency, 90 Tottenham Court Road, London W1P 9HE.

Any person who does any unauthorised act in relation to this publication may be liable to criminal prosecution and civil claims for damages.

The author has asserted his right to be identified as the author of this work in accordance with the Copyright, Designs and Patents Act 1988.

First published 1999 by

MACMILLAN PRESS LTD

Houndmills, Basingstoke, Hampshire RG21 6XS and London

Companies and representatives throughout the world

ISBN 978-0-333-58869-7

DOI 10.1007/978-1-349-27623-3

ISBN 978-1-349-27623-3 (eBook)

A catalogue record for this book is available from the British Library.

This book is printed on paper suitable for recycling and made from fully managed and sustained forest sources.

Published in the United States of America 1998 by

ST.MARTIN'S PRESS, INC.,

Scholarly and Reference Division,

175 Fifth Avenue, New York, N.Y. 10010

ISBN 978-0-312-22207-9

ISBN 978-0-312-22208-6 
For Daisy and Sam 


\section{ConTEnTs}

List of Tables

Preface ai.d Acknowledgements

1 Europe and the 'Third World': An Introduction and Overview

The Structure of this Book

2 Europe and the Americas 24

Introduction $\quad 24$

Demography and Labour in the 'New World' 27

Black Slavery in the Americas $\quad 30$

Bullion, Price Inflation and the Rise of a

Transatlantic Trading System

The 'Europeanisation' of the Caribbean and the 'Americanisation' of Europe's Long-Distance Trade 41

Slavery, Capitalism and Industrialisation $\quad 47$

Conclusions: Europe and the New World 56

$3 \quad$ Europe and Asia, $c .1500$ to $c .1880 \quad 59$

Introduction $\quad 59$

Between the Asian Trade Revolution and the Beginnings
of Territorial Conquest

India's Potential for Autonomous Development 76

The Incorporation of the Indian Subcontinent into the

Failed 'Revolution From Above' in India? $\quad 87$

Nineteenth-Century Java: from the Cultivation System

Conclusions $\quad 95$

4 Europe and Africa from the Slave Trade

to the Colonial Conquest

$\begin{array}{ll}\text { Introduction } & 100\end{array}$ 
The Slave Trade, Slavery and African Underdevelopment 102 'Legitimate Commerce' and the Traders' Frontier 107

The Partition of Africa and the 'New Imperialism' 113

Europe, Egypt and Morocco

The 'Mineral Revolution' and White Power in

Southern Africa

Colonial Regimes in Tropical Africa before 1914

Making Good the Claims: The Development of Colonial Africa

until 1914 and its Incorporation into the World Economy

Conclusions

5 European Colonialism and Indigenous Society in Asia

Introduction: The Debate over Colonialism and Development

India

Indian 'Underdevelopment' and the International Economy

The Dutch East Indies in the International Economy

Retarded Industrialisation in India: 1870-1914

The Origins of Economic Sovereignty and Withdrawal

from the International Economy: 1914-39

India: The Land and the Law

Conclusions: Colonialism, Modernity and Capitalism in Asia

6 The Economic and Social Consequences of

Modern Colonialism in Africa

Introduction

Indirect Rule and 'Native Policy'

'Settler' and 'Peasant' Regimes

Abortive Late 'Settlement' in Portuguese Africa

The 'Cash Crop Revolution' and 'Incomplete' Capitalist

Development

Mining and Economic 'Dualism'

Did Colonialism Impoverish Africans? 
The Balance Sheet of Dutch Colonialism 245

The Balance Sheet of Portuguese Colonialism 248

Conclusions $\quad 255$

8 The Political Economy of Decolonisation 257

Introduction: The Complexities of Decolonisation 257

The Three Perspectives on Decolonisation $\quad 259$

Colonialism in the Post-war World: France and Britain

Compared

Economic Modernisation, European Integration and

Decolonisation: the Basic Connections

273

Europe, and Belgian and Portuguese Decolonisation 278

The Economic Calculus in the Decolonisation Process 280

'Neo-colonialism' and Economic Decolonisation 290

The European Economic Community and the ACP 296

Conclusions: Decolonisation and the Emergence

of the 'Third World'

299

9 Europe and the 'Third World' in Retrospect 306

$\begin{array}{lr}\text { Bibliography } & 315\end{array}$

Index $\quad 343$ 


\section{LIST OF TABLES}

5.1 British trade with India 1870-1914

5.2 Annual per capita value of India's international merchandise trade

5.3 Indian exports to main trading partners 161

5.4 Main Indian commodity exports 161

7.1 World output of industrial resources in the late 1920s 226

7.2 The part of the French empire in French external trade 229

7.3 French external investments 1882, 1902, 1914

7.4 Share of the Portuguese colonies in Portugal's external trade $\quad 252$

8.1 French capital invested in overseas France 265

8.2 French colonial trade as a proportion of total French commerce 1946-56 266

8.3 French and British trade with colonies and ex-colonies, 1960 and 1972 


\section{PrefaCe AND AGKNOWledgements}

'Europe' and the 'Third World' are vague geographical terms with strong political and cultural resonances. Despite the ancient origin of the word, 'Europe' is a relatively modern idea. It became the common term for the civilisation occupying the western promontory of the Eurasian land mass only around 1700 when it was adopted as a secular substitute for 'Christendom' (Davies, 1996, p. 7). The Enlightenment savants who popularised the expression identified Europe with liberty and moral and material progress in a commonwealth of sovereign states, partly by contrast with the stagnant despotism of Asian empires. Even the widely admired Chinese empire was regarded as a 'stationary' polity that had scarcely changed since Marco Polo's time. When Diderot's Encyclopédie appeared around 1760, the pre-eminence of 'Europe' amongst the world's civilisations was a philosophical commonplace. Though the smallest of the four quarters of the globe, it was - we learn - the most fertile, had the greatest commerce and navigation, was where the arts, sciences and professions were most advanced, and where the spirit of Christianity had fostered a certain conception of human rights not found elsewhere. Europe 'had arrived at such a degree of power, that history had almost nothing with which to compare it' (Encyclopédie article 'Europe').

The new science of political economy offered a cogent explanation as to why Europe was the most materially progressive part of the globe, and helped articulate European self-consciousness: Adam Smith taught that national product grew through the generalisation of the social division of labour and the specialisation of economic function. The optimum preconditions for growth occurred where self-interested property owners acting under the rule of law enjoyed the greatest market freedom. These preconditions were absent in Asiatic states, where sovereigns claimed universal ownership of the land, and best realised in Holland and England. One could deduce from Smith that the more the European states abandoned their exclusive trade policies and corporate restrictions on manufacturing, then the more Europe as an emergent economic entity 
constituted by international trade and an international division of labour would acquire a 'real' existence. But it is debatable whether Smith would have welcomed any lessening of Europe's national and cultural diversity: in the empiricist philosophical tradition to which he belonged, the perception of human character differences, and the emulation of remarkable individuals by the mediocre, was a crucial mechanism of social progress. Smith's disciple, John Stuart Mill, was later to argue that it was 'the remarkable diversity of character and culture' in the European family of nations that had made them 'an improving, instead of a stationary portion of mankind'. Europe was wholly indebted for 'its progressive and many-sided development' to the plurality of paths taken by its individuals, classes and nations (Mill, 1859, 1975 edn, p. 89).

If Europe connoted liberty and material progress, market integration and national and cultural diversity, it was also associated with the geographic expansion of the military-political power of the Atlantic states, along with their social institutions and ideologies. Enlightened Europeans knew that the indigenous peoples had fared disastrously in the post-Columbian Americas and that commercial agriculture there was widely dependent on slavery, a mode of labour exploitation increasingly condemned on moral and economic grounds. Nevertheless, their reflections on European maritime expansion helped clarify their perception of Europe as the centre of human development, and this understanding of the world could only become engrained in subsequent generations. In the century and a half after Diderot and Smith published, the modern world's political geography was largely determined by the expansion of European states and states of European origin. By 1800, they had staked out claims to about 55 per cent of the earth's surface, and effectively controlled about 35 per cent. Apart from Europe's 4.4 million square miles, a further 13.5 million square miles of territory in the Americas, the Tsarist empire in Asia, the Indian subcontinent, the Indonesian archipelago and coastal Africa were under European or Euro-American political sway. By the late 1870s, before the onset of the 'new' imperialism, the existing political claims had been consolidated and new ones asserted, to a point where two-thirds of the world's land mass was under Western dominion. In 1914, it was about four-fifths (Clark, 1936, pp. 5-6).

Sometime between Mussolini's conquest of Ethiopia in 1935 and the British surrender of Singapore in 1942, European military-political power ceased to be the monstrous shaper of world history. The continent's partition between antagonistic blocs after 1945 so suppressed the idea of 'Europe' as a region of shared history and culture from the Atlantic to the Urals that a handful of states in the West could surreptitiously appropriate the name for 
their customs union. Until Mikhail Gorbachev rediscovered the 'common European home', they were abetted in their linguistic larceny by the repression of European consciousness and sentiment in the Soviet bloc. This ideological narrowing of 'Europe' was, undoubtedly, facilitated by the dramatic reduction of European power and influence in the wider world. France and Britain failed abysmally in attempting to coerce Egypt in 1956, and their colonial empires in Asia and Africa were soon to be wound up. The European international system, under whose aegis the modern state had become a universal form of political organisation, was overshadowed by opposing alliances, each dominated by an extra-European superpower. With the retreat of Europeans from the wider world, the idea of 'Europe' could more easily be attached to an inward-looking union of Western European states. I fear this book - which ignores, for reasons of space, Tsarist and Soviet Russian expansion into Asia - has imitated that casual misappropriation. The 'Europe' of my title is, first, the Atlantic Europe which turned the oceanic boundary of the continent into the highways of intercontinental exchange; second, the European metropoles that acquired formal and informal dependencies overseas; third, the 'core' national economies of an expansive capitalism; lastly, the dominant Western powers in the system of absolutely sovereign and juridically equal modern states.

My second term, the 'Third World', was coined by the French demographer, Alfred Sauvy, in August 1952 when the cold war was at its most frigid, and actual conflict dragged on in Korea. The USA and the Soviet Union could plausibly represent themselves as leading two 'worlds', with different social and political systems and ideologies, whose antagonism was so pervasive as to exclude all possibility of neutrality. In these critical international circumstances, where humanity's future seemed to lie either in general war between capitalism and communism or in indefinite hostile coexistence, it was - Sauvy argued - too easy to ignore the 'tiers monde' of 'underdeveloped' countries. Like the Third Estate in 1789, 'This third world, ignored, exploited, scorned, wishes to stand up for itself ('Trois Mondes, une planète', an article written for L'Observateur, 15 August 1952). It was some years before Sauvy's coinage was given wider academic circulation in the collection of essays edited by Georges Balandier, Le 'tiers monde', sous-développement et développement (1956), and adopted by the review Tiers monde published from 1960 by the Institut Economique et Social de l'Université de Paris. More significantly, in terms of the political potency of the expression, the 'Third World' gained currency amongst émigrés from North Africa, and other French colonial territories, in Paris, many of whom were readers of L'Observateur (Lacoste, 1980, vol. 1, pp. 10-29). 
With the outbreak of the Algerian war of independence in 1954, 'Third World' political consciousness developed in step with this increasingly bitter anti-colonial struggle. Its most eloquent voice was that of Franz Fanon, the Martinique-born doctor who had practised in Algeria, and later helped edit the National Liberation Front's newspaper from Tunis. In The Wretched of the Earth (first published in French in 1961), Fanon projected an eschatological vision of the redemption of humanity by the dispossessed peasantry of the 'Third World' - a vision which captured the imagination of the noncommunist left during the upheavals of 1968-9, the apogee of 'tiersmondisme' as a loosely articulated revolutionary ideology and concept of global divisions (Lacoste, 1980, p. 18). Fanon contrasted the inhuman poverty of the underdeveloped world with Europe's scandalous 'opulence' that had been founded on slavery and racist exploitation, and demanded restitution for the European plundering of the 'Third World':

The wealth of the imperial countries is our wealth too . . For in a very concrete way Europe has stuffed herself inordinately with the gold and raw materials of the colonial countries: Latin America, China and Africa. From all these continents, under whose eyes Europe today raises up her tower of opulence, there has flowed out for centuries towards that same Europe diamonds and oil, silk and cotton, wood and exotic products. Europe is literally the creation of the Third World (Fanon, 1969, p. 81).

During the 1960s and in 1970s, this notion of the 'Third World' as those areas of the globe exploited by Europe in the course of, and as a necessary condition for, its own development dovetailed with 'dependency' and 'world systems' theory (discussed in Chapter 1) and retains today a powerful hold on the non-Western intelligentsia. Thus, in the Third World Guide - a gazetteer purporting to show the world as seen by the 'Third World' - we find arguments with an obvious family resemblance to Fanon's claims. The editors regard a historical viewpoint as essential to understanding what the 'Third World' is, and identify it with the periphery of the system produced by the expansion of world capitalism whose development they regard as a global zero-sum game:

The so-called 'underdevelopment' of the Third World is the underside of today's 'development' of the industrialised capitalist powers, whose wealth was and still is to a great extent drawn from the Third World through direct (Latin American gold) or indirect (cheap Middle-eastern oil) plunder (Third World Guide, 89/90, p. 12). 
The editors define the common characteristics of the 'Third World' countries as:

First, the fact of having previously been colonies of foreign powers; second, the fact of having suffered economic exploitation which shaped their production systems to make them exporters of raw materials and deprived them of the power to make decisions on the basis of people's interest . . . Finally, cultural domination, that has created an inferiority complex with regard to the national cultures, imposing as universally valid the values of 'Western Christian Civilization' ... (ibid., p.13).

Of course, these are the certainties of a committed publication written in a deliberately populist style. I quote them, not as a target for facile refutation, but to show how the self-understanding of the 'Third World' is bound up with the notion of a global rift between 'have' and 'have not' societies opened by the geographic expansion of capitalism from its European base.

For some time now, scholars of all persuasions have urged that the concept of the 'Third World' has outlived its usefulness in the analysis of global society. Peter Worsley, who introduced it into Anglophone social science (Worsley, 1964), made the last sustained attempt to justify its use in The Three Worlds (1984). He argued that

The various meanings with which the [Third World] has been invested show family resemblances, even though they do not fully coincide. They have, that is, a common referent in the real world out there: the unequal, institutionalised distribution of wealth and poverty on a world scale (Worsley, 1984, p. 339).

Logically, a 'third' world requires the prior existence of a first and second, and it was still possible in the mid 1980s to identify these with the industrialised, capitalist 'West' under the leadership of the United States and the state socialist economies of the Soviet bloc. The 'Second Cold War' of the Reagan-Brezhnev years had re-clarified the political identities of two antagonistic social systems after a period of détente. The 'Third World' itself had some political identity in the Non-Aligned Movement - dating from 1961 - and the (overlapping) Group of 77 developing countries formed in 1964 after the first United Nations Conference on Trade and Development. Admittedly, a 'three worlds' schema blanked out the great fissure in world communism since 1963, when communist China had openly 'split' from the Soviet Union. But if the logical political conditions were just about satisfied in 
the mid 1980s, they had crumbled away by 1990 with the collapse of the Soviet bloc, economic liberalisation in the former 'command' economies and their closer integration with world markets.

Even before the dissolution of the 'second world', the concept of a 'third' was being challenged by the mounting evidence of economic differentiation among the developing countries, especially with the rapid industrialisation of the Pacific Rim economies. Their high growth rates were due principally to great increases in labour force participation combined with massive public and private investment, but they also exported a large proportion of their gross domestic products. An increasing prosperity due to competitiveness on world markets was quite contrary to the thesis advanced by 'dependency' theorists in the 1960s that foreign trade impoverished the developing countries and 'locked them' into a condition of 'underdevelopment'. After reviewing the experience of the newly industrialising countries, Nigel Harris pronounced the end of the 'Third World' in 1986, along with the decline of the radical ideology associated with the notion 'dependency'. For Harris, the developing countries were experiencing accelerated capitalist growth from a position of comparative backwardness, and he restated the 'classical' Marxist argument that as capitalism advanced throughout the world, so the distribution of its income and wealth would be determined by the class divisions and struggles within national economies. There were, of course, 'rich' and 'poor' countries in the sense of huge discrepancies in average per capita income but, contrary to Worsley, Harris saw no 'institutionalised' processes maintaining these differences. The 'Third World' could not be defined as those countries permanently disadvantaged by a common location in global capitalism. It was, in fact, a myth (Harris, 1986). Paul Kennedy, surveying the global divisions from the perspective of a liberal historian in the early 1990 s, concurred: the term had been made redundant by the discrepancy in economic performance between East Asia and sub-Saharan Africa. The differences in non-Western economies demanded a more complex categorisation of developing countries (Kennedy, 1993, p. 194).

As with so many mythological terms, the 'Third World' has maintained a vigorous public life long after academics declared its redundancy. Whatever the empirical and conceptual objections raised against it, the expression clearly fulfils a key function in categorising human society, as a casual reading of the press will attest. To cite one instance, Harold James, a distinguished historian of Germany, referred in a review in The Times Literary Supplement (13 June 1997) to 'the search for a third way' between capitalism and communism in the final phase of the German Democratic Republic as 'a way 
into the Third World'. Little, one suspects, was intended apart from literary effect, but a stylistic device will not 'work' on its readers unless they and the author have some common understanding of its terms. Though I share the scepticism of Harris and Kennedy about the idea of the 'Third World', I have retained the expression partly because, bound in with the common understandings of what the 'Third World' is, are powerful though imprecise notions of how it came to be so. One such notion associates 'Third World' countries with 'post-coloniality', and so refers us both to their derivative political origins as the former colonies of the expansive European or Western states and to the hybrid subaltern cultures formed where the colonialists' languages became the media for indigenous literary expression. Of course, 'post-colonial' invokes a past not only for the 'Third World' but also for the former colonisers who exploited its plantations and mineral wealth, and induced its peasants to cultivate cash crops for export. Nearly all Western European states are 'post-colonial powers', and only a generation ago even the most parochial was seen by its national élite as having an extraEuropean dimension. The phrase 'Belgian-Congolese community' was on everyone's lips in the corridors of Brussels in the later 1950s (Stengers, 1989, p. 225). But, like the 'Third World', 'post-colonial' is an open invitation to sceptical empiricism: what can it mean to say that Kinshasa and Singapore are both 'post-colonial' cities? Does it help explain their extraordinarily divergent fortunes since decolonisation? I share this scepticism. Indeed, I think 'post-colonial' bundles a host of non-European states and societies into a common history almost as mythological as the present-day 'Third World'.

This book grew out of an essay on 'Europe and the Third World' that I wrote for a collaborative course What is Europe?, produced by a consortium of European distance-teaching universities. I am grateful to Routledge and the the Open University for permission to re-use some of the material that appeared in that essay (Waites, 1993). What interested me originally was how (or whether) European expansion related to the uneven pattern of global development and the gross inequalities in income and welfare across the world. But this could be called a 'metahistorical' interest which prompted the reading and writing: it is not a historical problem that can be addressed square-on, and it certainly has no simple answers. The best I could manage was to follow that interest but break down the messy and often imperfectly known history into discrete topics. Though some chapters refer to centuries, and depict secular processes with a broad brush, my method has been to focus on specific historical questions. Even the most problem-oriented historical writing cannot dispense altogether with a narrative framework, but 
I have tried throughout to make narration serve the purposes of explanation. Each chapter can be read independently, but I hope that cumulatively they amount to a historical argument. To reduce publishing costs, I have consolidated the bibliography and used the detestable author-date referencing system.

I am grateful to the following for permission to use copyright material in statistical tables: Macmillan Press Ltd for data from B.R. Mitchell's invaluable compilations, International Historical Statistics: Africa and Asia and International Historical Statistics: Europe, 1750-1988; Editions Albin Michel for the use of data from Jacques Marseille's Empire Colonial et Capitalisme Français; Presses Universitaires de France for data from René Girault's contribution to the Histoire économique et social de la France; Columbia University Press for data from Grover Clark's The Balance Sheets of Imperialism; the editor of the Revue d'Histoire Moderne et Contemporaine and Jacques Marseille for data which first appeared in that journal; and the editor of the Oxford Bulletin of Economics and Statistics and Ian Livingstone for data from the bulletin.

This book has been purgatory to write; I can only hope it will be more pleasurable to read. Dr Gary Thorn read an earlier draft of Chapter 8 and the present version, however imperfect, was much improved by his comments. Otherwise, this has been a solitary task. The usual disclaimer that the mistakes are solely the author's comes from the heart. Daisy and Sam, for whom Europe and the Third World has long been a matter for patronising derision, would be really embarrassed if they knew it was dedicated to them. It's the only revenge left to me. 